ESCRITAS Vol. 9 n. 1 (2017) ISSN 2238-7188 p. 61-78

\title{
HISTÓRIA DE MUITAS VIDAS: MEMÓRIA DOS ÍNDIOS DO PIAUÍ
}

\author{
HISTORY OF MANY LIVES: MEMORY OF THE INDIANS FROM \\ PIAUÍ
}

\author{
Rafael da Silva Assis ${ }^{1}$ \\ Euclides Antunes de Medeiros ${ }^{2}$
}

\begin{abstract}
RESUMO: Em "História de Muitas Vidas" O nosso interesse foi problematizar narrativas orais dos remanescentes dos indígenas Pimenteiras do Território Serra da Capivara-PI. As narrativas em questão estruturam-se a partir das vivências dos entrevistados: elementos do cotidiano, as histórias contadas pelos mais velhos, a organização social, enfim, elementos de sua cultura reveladores de que são orientados por uma estrutura de sentimentos que permeia a vida dessas pessoas. Entrevistá-las foi, em grande medida, conjugar as análises com o sentir das emoções despertadas pelas vozes dos entrevistados o que nos possibilitou perceber a linguagem como parte de uma estrutura de sentimento no campo conceitual que Raymond Williams (1979) nos apresenta como parte das emoções individuais e sociais, as tensões, as disputas, as estratégias sociais e culturais, permitiu instrumentalizar nosso olhar nesse campo da linguagem oral, da narrativa oral, campo esse, sempre em disputa.
\end{abstract}

PALAVRAS-CHAVE: Memória; Indígenas; Serra da Capivara.

ABSTRACT: In "History of Many Lives" Our interest was to problematize oral narratives of the remnants of the indigenous Pimenteiras of the Serra da Capivara-PI Territory. The narratives in question are structured based on the experiences of the interviewees: elements of daily life, stories told by older people, social organization, and elements of their culture that are guided by a structure of feelings that permeates these people's lives. Interviewing them it was a great extent, combining the analyzes with the feeling of the emotions aroused by the interviewees' voices, which enabled us to perceive language as part of a conceptual framework that Raymond Williams (1979) presents as part of individual and social emotions, tensions, disputes, social and cultural strategies, allowed us to instrumentalize our gaze on this field of oral language, oral narrative, this field, always in dispute.

KEYWORDS: Memory; Indigenous; Serra da Capivara

Introdução

\footnotetext{
${ }^{1}$ Professor de História (SEDUC-PI). Mestre em Ensino de História pelo Programa de Pós-Graduação em Ensino

2 Doutor em História pela Universidade Federal de Uberlândia (UFU) e professor do Programa de PósGraduação em Cultura e Território (PPGCult), na Universidade Federal do Tocantins (UFT). Coordena o Grupo de Pesquisa "História Regional: memórias e territorialidades".
} 
Durante muito tempo, ouvimos não existir mais índios no estado do Piauí. As narrativas escritas dão destaque ao extermínio, considerando o século XIX como marco do fim dos indígenas no estado. Investigando as narrativas da tradição oral percebemos divergências entre narrativa oral e escrita, subterrânea e oficial (POLLAK, 1989).

Os traumas, as tensões, as clivagens sociais, as paixões, a dor, o medo estão aqui relacionadas sob o fio da memória das famílias indígenas do Território Serra da Capivara ${ }^{3}$. Até pouco tempo a presença dos índios do Piauí era relegada ao esquecimento. Por muitos anos acreditava-se no extermínio dos índios do Piauí. A memória sempre está em conflito, em uma construção permanente entre o que deve ser lembrando e como deve ser lembrado, o que deve ser esquecido e como deve ser esquecido. Muitos dos portadores da memória foram descendentes de indígenas, assassinados de forma brutal. Os filhos, os netos, os sobreviventes do holocausto indígena, se propuseram a manter-se em silêncio por conta da dominação e sofrimento. A memória dos sobreviventes era e é ainda, em larga medida, uma memória interditada. Entretanto, aos poucos, ela constrói novos significados e recebe novas interpretações.

Essa memória dos sobreviventes reativada pelos seus descendentes é o que Beatriz Sarlo caracteriza como "pós-memória" [que] se designaria a memória da geração seguinte àquela que sofreu ou protagonizou os acontecimentos (quer dizer: a pós-memória seria a 'memória' dos filhos sobre a memória dos pais)". (SARLO, 2007, p. 91.). Ainda sobre o caráter traumático da memória de "sobreviventes" Ricoeur alerta que os relatos "erigem-se em nome de todos os acontecimentos que deixaram sua impressão traumática nos corações e nos corpos: protestam que foram e, nessa condição, pedem para ser ditos, narrados, compreendidos". (RICOEUR, 2007, p. 505.)

Quando problematizamos a história indígena, sob a égide da história oral, lançamos mão do espectro da memória traumática. Nesse sentido nos debruçamos sobre uma constituição familiar indígena, pautada em uma violência fundadora. É recorrente nas narrativas transmitidas pela oralidade que as mulheres indígenas eram pegas a dente de cachorro, sendo muitas estupradas e, posteriormente, passavam ao convívio com o homem branco por meio de casamentos. A expressão "pegas a dente de cachorro" e outras afins como

\footnotetext{
${ }^{3}$ O Parque Nacional Serra da Capivara é uma unidade territorial de conservação brasileira de proteção integral à natureza localizada nos municípios do Estado do Piauí Canto do Buriti, São João do Piauí, São Raimundo Nonato e Coronel José Dias. O trabalho empírico foi realizado neste último.
} 
"pegas no laço" nos remete às práticas de apresamento dos indígenas e que são reveladoras de uma dada memória social. Os espectros de uma memória proibida, da memória do trauma que ainda rondam os indígenas do Piauí.

\section{O IMBUZEIRO DAS ALMAS}

Na pequena cidade de São Lourenço do Piauí, os moradores locais contam que, próximo a um imbuzeiro, há aparições de fantasmas ou o que eles chamam de "livursias" [aleivosias], essas assombrações, segundo a tradição oral, contada pelos moradores mais velhos, seriam os "cabocos bravos", forma por meio da qual ainda nomeiam os indígenas em questão e que teriam sido assassinados e enterrados nas proximidades do imbuzeiro. As memórias dos moradores mais velhos estão ligadas com o presente e sua relação como o passado. Os fantasmas do presente relacionam-se com os traumas do passado, por isso acreditamos que a memória é permeada também pela factualidade, assim como as impressões de quem narra.

$\mathrm{Na}$ pesquisa intitulada, umbuzeiro dos defuntos: um marco na história de São Lourenço do Piauí, os arqueólogos da Universidade Federal do Vale do São Francisco, Celito Kestering e Gizelle Santos de Sousa utilizam três narrativas orais de moradores da pequena cidade de São Lourenço. Nas três narrativas podemos destacar a memória herdada de seus avós que, reavivada por algumas gerações, traz à tona o medo das assombrações. Outras narrativas afirmam que ali foram assassinados e enterrados centenas de índios, a memória traumática parece ser o grande motivador para uma tentativa de esquecimento da herança indígena.

\footnotetext{
A memória é a vida, sempre carregada por grupos vivos e, nesse sentido, ela está em permanente evolução, aberta à dialética da lembrança e do esquecimento, inconsciente de suas deformações sucessivas, vulnerável a todos os usos e manipulações, suscetíveis de longas latências e de repentinas revitalizações. (NORA, 1993, p. 09).
}

Em relação à pesquisa umbuzeiro dos defuntos, acima referida, os depoimentos nos ajudam a pensar a memória traumática. No depoimento de Maria Belém Vilanova Santos ela fala por meio de sua memória herdada pelos avós e bisavós, e segundo essa memória herdada o imbuzeiro era o lugar onde foram enterrados índios. No local é comum aparição de assombrações, barulhos e pessoas conversando: 
[...] meus avós e bisavós falavam que era lugar de índio. Devido às fileiras de pedras, eles diziam que era lá onde eles (os índios) enterravam os mortos, por isso o nome. Lá tinha umas aparências e assombrações como luzes, pessoas conversando, barulho de cavaleiros com seus cavalos. As pessoas até se recusavam a passar lá durante a noite. Eu, inclusive, passei por lá nestes dias e vi que as pedras ainda estavam lá, meio enterradas. No riacho da pedrona também tinha marcas que meus avós falavam ser de índios devido às cercas de pedra. Pode ser que eles usavam pra marcar terras. Com o tempo não tem mais não, mas tinha (KESTERING; SOUSA, 2014, p. 128).

A narrativa de Florinda Ferreira dos Santos é bem parecida com as demais narrativas, novamente é destacado o lugar como sendo um cemitério indígena e onde ocorrem aparições de assombrações:

Lá tem um morro de pedra. O povo diz que lá era lugar de índio, onde eles enterravam os seus mortos. Lá tinha e tem ainda assombração. A finada tia Josefa um dia passou por lá com uma cesta de mandioca. Aí, num sopapo, derrubaram a cesta. Engraçado era ela falando que as mandiocas dela eles não iam levar não. Ela fez um tição de fogo para alumiar e pegou todas as mandiocas. Lá é mesmo lugar de índio. Meus avós e bisavós sempre falavam. Não é só nesse lugar que tem restos de índios. No salãozinho, debaixo do juazeiro, também acharam ossos que pareciam ser de gente. Falavam que eram de índios (KESTERING; SOUSA ,2014, p.129).

Andrelino Farias Damasceno em sua narrativa comenta uma palavra corriqueira entre os moradores da região, "livursia" (aleivosia), palavra usada para falar de assombrações, almas e zumbidos:

Antigamente tinha uns lajedos de pedra que o povo falava que eram de índios. Eles moravam lá. O nome (Umbuzeiro dos Defuntos) eu acho que é porque o povo falava que tem aleivosia lá onde eles enterravam os seus mortos. Chamam também de imbuzeiro das almas. É lá por aquelas bandas de lá que era o centro de São Lourenço. Meu pai dizia que aqui tinha uma geração de índios que foram corridos daqui e ficaram poucos. (KESTERING; SOUSA, 2014, p. 129).

As três narrativas mostram bem a complexidade da memória e o acirramento entre memória coletiva e memória subterrânea, à medida que a representação construída sobre os indígenas os remetem à condição de espectros, de aleivosias, de fantasmas, sendo a única sombra de materialidade de suas existências as pedras que marcam o lugar do possível sepultamento. A memória sempre está em conflito, em uma construção permanente entre o que deve ser lembrando e como deve ser lembrado, o que deve ser esquecido e como deve ser 
esquecido. Muitos dos portadores da memória foram descendentes diretos dos primeiros indígenas, assassinados de forma brutal. Os filhos, os netos, os sobreviventes do holocausto indígena, se propuseram a manter-se em silêncio por conta da dominação e sofrimento. A memória dos sobreviventes era e é ainda uma memória proibida, entretanto, aos poucos ela ganha novos significados, novas interpretações.

\section{OS DIAS-MARRECA}

Os fios que utilizamos para urdir a trama desse trabalho foram as memórias dos remanescentes indígenas das zonas rurais das cidades de São Raimundo Nonato, Coronel José Dias, Caracol, Jurema, São Braz do Piauí e São Lourenço do Piauí. As narrativas foram produzidas principalmente por meio das entrevistas concedidas por moradores de diferentes lugares de memória. No labor do campo de pesquisa, percebemos feixes de memórias, num emaranhado de fios. Laborar com esses fios, pressupôs entrar em contato com a vida dos entrevistados, e eles entrarem em contato com a vida do entrevistador. As narrativas dos entrevistados foram construídas artesanalmente, em conversas, observações do lugar, com intervenções de terceiros nas falas. O olhar do pesquisador no ato produção das entrevistas também tem uma articulação com os teóricos que instrumentalizam nosso olhar. Allesandro Portelli nos ajudou pensar a história oral e o campo de pesquisa:

Este assume um papel diferente daquele que em geral é atribuído a quem realiza pesquisas de campo: mais do que "recolher" memórias e performances verbais, deve provocá-las e, literalmente, contribuir com sua criação: por meio da sua presença, das suas perguntas, das suas reações. A diferença cultural entre pesquisador e narrador sujeita este último a estímulos imprevistos, força-o a explorar setores e aspectos da sua experiência que geralmente não são mencionadas quando ele conta histórias ao seu círculo imediato (PORTELLI, 2010, p.20).

Entre os lugares que percorremos conduzidos pelo o fio da memória, podemos destacar as narrativas orais do assentamento Saco, zona rural da cidade de Caracol como sendo as mais promissoras para esta pesquisa. Terreno fértil e conflituoso entre a relação de história e memória, lá encontramos figuras centrais da pesquisa, a família Dias-Marreca. Os Dias-Marrecas são os descendentes diretos dos indígenas que habitaram a região do vale do rio Piauí. 
O nome Dias-Marreca vem da união entre uma indígena por nome Marreca e um homem branco por nome Manoel Dias Soares. A união entre os dois ocorreu no século XVIII, Manoel Dias Soares era filho do cabo José Dias Soares, responsável pela colonização e foi um dos responsáveis pela guerra contra os índios Pimenteiras, habitantes do vale do rio Piauí. O conflito entre indígenas e colonizadores resultou no sequestro de Manoel Dias Soares levado a cabo pelos índios Pimenteiras. Manoel Dias Soares tinha 14 anos quando foi sequestrado, "este desapareceu nas matas por tanto tempo que todos supunham morto" como medida de vingança dos indígenas, "após mais de quarenta anos, quando ninguém o esperava mais, apareceu Manoel Dias trazendo à frente uma récua de dez ou doze filhos gerados na índia de nome Marreca, da tribo dos Pimenteiras" (DIAS, 2003, p.104). Em seu retorno Manoel Dias Soares não se adaptou aos costumes e convívio de sua família branca, devido a isso, seus parentes brancos acomodara-o juntamente com seus filhos e a indígena Marreca em uma das fazendas de José Dias Soares, que hoje é o assentamento Saco, zona rural de Caracol-Pi.

O Assentamento Saco é organizado em três núcleos residenciais, Sede, Serrinha e Calaboca e no núcleo Sede existe uma agrovila. O Assentamento fica distante $77 \mathrm{~km}$ de São Raimundo Nonato e $11 \mathrm{~km}$ da zona urbana de Caracol. As terras onde hoje está localizado o assentamento foi uma antiga fazenda pertencente ao cabo José Dias Soares e no transcorrer do tempo passou por outros donos, moradores e famílias diferentes. As terras foram desapropriadas cerca de quinze anos atrás, do seu ultimo dono, Francisco Mariano, conhecido como Chico Gancho. Por volta de 1996 foi criada a associação dos moradores da comunidade Saco, e dai em diante pessoas de diversas localidades de Caracol ocuparam as terras da fazenda Saco, construindo pequenas choças e pequenos roçados. Algumas famílias já moravam na fazenda e trabalhavam para seu último dono, Chico Gancho. Anos mais tarde o assentamento Saco foi regularizado pelo INCRA, e outras comunidades do seu entorno foram anexadas ao assentamento. Na parte que compreende a antiga fazenda mora por volta de 600 pessoas, sendo ela a maior comunidade da zona rural de Caracol.

A família de sobrenome Dias-Marreca, vive espalhada principalmente pelas zonas rurais das cidades de Caracol e Jurema, há membros que vivem na zona urbana de Caracol e São Raimundo Nonato, todavia, o ponto de referencia da família ainda continua sendo a Comunidade Saco, lugar da união da família Dias com a indígena Marreca. Dos traços étnicos da família Dias-Marreca, percebe-se uma mistura entre o índio e o negro. Os documentos do século XVIII já relatavam a união étnica entre índios, e negros fugidos de fazendas da região. 
Ao chegar à comunidade Saco, nos deparamos com um enorme "pé de juazeiro", ponto de referencia para localizar uma comunidade que fica nas margens de uma "BR" que dá acesso ao estado da Bahia. Mas nossa primeira referência sobre o lugar foi por meio de uma fala de uma senhora com aproximadamente 70 anos, moradora da zona urbana de Caracol que informou ser lá "a terra dos caboco bravo". A senhora usa o termo caboco bravo de forma pejorativa para falar dos moradores da comunidade Saco. É pela expressão "lá é a terra de caboco bravo" que iniciamos nossa problematização, primeiro porque se trata de um lugar de memória (a terra de caboco), segundo porque se trata da identidade do outro, do visto como diferente (lá é a terra dos cabocos). A narrativa da senhora que me reportei serve para exemplificar o olhar exterior, o olhar dos outros, e como a memória coletiva atribui lugares.

A "terra de caboco bravo" não se encontra isolada, na verdade é um "lugar comum", um lugar da memória coletiva, e, nesse sentido, as memórias sobre a terra dos cabocos são construídas pelo testemunho dos outros. A princípio, no senso comum, acredita-se num purismo da memória, que seriamos os possuidores originários das nossas lembranças. Como já vimos as narrativas da memória são construídas, não são ingênuas, o que nos remete ao questionamento: a memória está a serviço de quem? A seguir apresentaremos narrativas orais que mostram os conflitos entre memórias discordantes. As narrativas orais que problematizamos deixam vazar os confrontos entres memórias.

O nosso primeiro entrevistado nada se assemelha com os traços físicos do que comumente se pensa ser um descendente de indígenas, não tem o sobrenome Dias-Marreca, mas é do grupo familiar dos Dias-Marreca. Ronivon foi nosso guia dentro da comunidade, nos apresentou as primeiras histórias de lá. E em sua fala destaca como os outros moradores da zona urbana de Caracol e até mesmo do assentamento Saco veem a família dos Dias-Marreca, uma visão que vaza o conflito entre reivindicação e negação de memória, uma memória indígena.

Foi criada uma memória negativa acerca dessas pessoas chamadas de cabocos bravos, em geral são tratadas como "indivíduos de inexpressível valor social”. Nas narrativas da família Dias-Marreca, destacam que o termo caboco é usado principalmente para relacionálos como povo de baixo nível cultural, de baixa escolaridade e de pouca perspectiva de vida:

Eh! No entanto, eu poderia começar essa fala dizendo o seguinte: que é ... Uma etnia, é uma classe, existe um termo para se designar ao se tratar de certa etnia, não só na comunidade Assentamento Saco, mas já vem de Caracol de uma forma geral, eu acredito que em outros áreas também 
aconteça algo parecido, a se referir ao um certo povo, grupo de pessoas de famílias como cabocos. Cabocos é um termo que é pejorativamente usado né, e se vem se perpetuando por muito tempo ao se tratar de pessoas que eles [os "outros"] consideram, pessoas de baixo nível cultural, de baixa escolaridade, de pouca perspectiva de vida né, é o que se observa quando eles falam dos cabocos em si (ROCHA, 2016).

É importante destacar que boa parte da família Dias-Marreca se reconhece como povo indígena, porém, as narrativas que foram construídas, representando-as como pessoas de "pouco valor social", acarretam diretamente na falta de autoconfiança, de orgulho e, em certa medida, na auto identificação como indígena. A temática indígena é silenciada por muitos moradores da comunidade:

E o interessante em se ver ... Em se entender isso é que esse desarranjo enquanto a presença do indígena ou daquele cuja origem de identificação tá bem mais associado do ponto de vista histórico, as vezes nem, não só de si mesmo né, as vezes não tem esse reconhecimento de si como indígena, mas conhecendo um pouco dessa história você percebe que as pessoas tem isso, você percebe que essas pessoas mesmo eles se desvalorizam, no seguinte sentido de ... De como se diz? Na questão da auto..., autoconfiança, da ... do respeito por..., Como diria? Da questão de valorização de identificação, eles se sentem fragilizados, aí você justamente vê o envolvimento né, dessa relação oprimido e opressor, é interessante colocar isso, agora sim, dar pra se entender que não é algo cabível, não algo de motivo de orgulho de alguém se identificar como indígena na própria comunidade né, não é algo de orgulho, pelo contrário é algo que se você ver muito escondido né, muito colocado de lado, se muda muito de discurso quando se traz essa temática. Não é essa identificação acredito assim ela... é... pode ... se houver ela há no interior de alguns, no interior de algum, mas a manifestação dessa, dessa certeza de que, de pertencimento né cultural indígena, é uma coisa que ficou muito, fica muito, como diria, abstrato, acho que há uma certa negação, invés de uma aceitação, uma certa negação, acho que é bem mais possível se negar a origem indígena do que realmente assumir essa origem indígena (ROCHA, 2016)

Durantes nossos esforços para compreensão das amnésias sociais, aquilo que a sociedade decide esquecer, nos deparamos principalmente com a problemática da memória traumática. É recorrente que as narrativas dos entrevistados sempre tentam explicar sua história a partir de elementos que vinculam a presença indígena com um trauma sofrido, esse trauma de certa forma é amenizado nos depoimentos, e não raro, é comum "matadores de índios", expressão corriqueira na região, serem alçados à condição de mito fundador de determinada comunidade, por exemplo, uma antiga comunidade (comunidade Zabelê) que 
estava dentro da atual área do Parque Serra da Capivara, tem como o mito fundador a figura de Vitorino, conhecido na memória coletiva como matador de índio. Na cidade de Caracol o mito fundador é o cabo José Dias Soares e sua família Dias, José Dias Soares foi o principal matador de índio da região, muito embora as narrativas amenizem sua figura como matador e destacam mais sua imagem como civilizador da região. A serviço de quem está a memória do trauma? A serviço de quem está a memória do matador de índio? O matador de índio é também uma produção simbólica do poder dos fazendeiros. O matador de índio é filho das sombras desse passado de instalação das fazendas. Vivendo em vilas esses fazendeiros contavam as façanhas de seus parentes. Não há dúvida de que os descendentes dos índios tenham que buscar na memória do matador as lembranças de sua própria história. É dentro dessa perspectiva que será problematizado as narrativas de Zé Dias, líder da família DiasMarreca.

Primeiramente, temos que nos situar nesse emaranhado de fios que se entrelaçam, que se distanciam e se reaproximam. Vejamos a complexidade dessa trama: nosso entrevistado Zé Dias é ligado diretamente ao "sangue" dos indígenas e também ligado ao "sangue" dos matadores de índio. O nosso entrevistado foi batizado com o mesmo nome do mais conhecido matador de índio da região (José Dias), portanto, as narrativas de nosso entrevistado, Zé Dias, estão entre a memória dos grupos indígenas que foram perseguidos e também entre a história dos colonizadores que vieram conquistar as terras dos índios. A memória subterrânea mais do que nunca entra em confronto com uma memória oficial construída pela elite, pelos herdeiros dos primeiros colonizadores.

José Dias, mais conhecido como "Zé Dias", por algum infortúnio não foi registrado em cartório com o sobrenome Dias-Marreca, seu legado é ser um portador da memória e da história dos Dias-Marreca. Zé Dias é um dos lideres da comunidade, por algum tempo foi presidente do Assentamento Saco, inclusive participando da construção do assentamento. Assim como a maioria dos moradores da comunidade Zé Dias é um pequeno agricultor, cultiva milho, mandioca, feijão é um homem simples e de fala "mansa", sua fisionomia deixa transparecer as interações étnicas ocorridas entre indígenas e negros e traços mais difusos do homem branco, sua família também tem constituição étnica parecida. Em relação à sua fala, transparece que uma de suas maiores preocupações era com a falta de chuva na região, preocupações de ordem cotidiana e prática, pois chuva significa plantio e colheita e, portanto sobrevivência. Tais preocupações ofuscam, relativamente, outras preocupações como a 
problemática dos indígenas. As preocupações de Zé Dias são também as preocupações de toda a comunidade que, em boa parte, vivem da agricultura de subsistência e de programas sociais como o Seguro Safra e o Bolsa Família. Desde 2013, a região vem passando por período de escassez de água e consequentemente queda na produção de alimentos:

\begin{abstract}
aqui o nosso plantio aqui, você sabe que o nordestino aqui a situação dele, o plantio nosso aqui é fejão, é milho, é mandioca, é essas coisas, e nois tamo já a cinco anos que não tem isso de jeito ninhum, não teve lavôra, principalmente nesse ano foi do anos piores que teve, que nois chegamos aqui, esse cinco ano cada ano, as vêis chove um pouco no início, dezembro, janêro, as vêis feverêro, março como aconteceu esse ano, nois tivemos chuva aqui só em janêro, teve a chuva em janêro, todo mundo plantou a planta chegou a crescer um pouco, agora ficou feverêro, março, abrili, tamo terminando agora, sem chuver de jeito ninhum, quer dizer a planta num resistiu, se você andar hoje aqui nas roça você tá veno a situação que milho, parte de milho cresceu oitenta cêntimo, um metro, trinta cêntimo e morreu ali mermo que não teve mais chuva (DIAS, 2016)
\end{abstract}

É perceptível que a partir da labuta cotidiana pela sobrevivência, em um primeiro momento, o sentimento de identificação é com o "nordestino" e não com o "indígena". Entretanto, mesmo havendo tal identificação não se percebe um sentimento de pertença já que Zé Dias enuncia o nordestino como sendo um "outro" por meio da enunciação "a situação dele". Havendo tal sentimento, provavelmente o enunciado seria "nossa situação".

Em relação à presença indígena na comunidade Saco, Zé Dias mostra em sua narrativa preocupações pessoais em relação à manutenção da memória da família Dias-Marreca e também traz uma narrativa importante. Durante a entrevista ele cita varias vezes o nome de William Palha Dias, mostrando que este Palha Dias compartilhava das mesmas preocupações de Zé Dias, quanto à manutenção da família Dias-Marreca. William Palha Dias foi um importante escritor literário e em sua obra, Caracol na História do Piauí, ele destina um tópico que trata da família Dias-Marreca. Por meio de sua narrativa trata os indígenas de forma pejorativa e enaltece a figura do cabo José Dias Soares, responsável pela colonização da região. José Dias Soares é tataravó de William Palha Dias. Zé Dias, como já dito antes, tem o sangue da indígena Marreca e também o sangue dos Dias, portanto tem parentesco tanto com o Cabo José Dias Soares consequentemente com William Palha Dias.

Zé Dias fala que William Palha Dias teve uma conversa com Martins Walter, exprefeito de Caracol, nessa conversa Palhas Dias propôs a criação de uma agrovila para receber apenas os Dias-Marrecas, descendentes dos indígenas. A narrativa de Zé Dias mostra também 
sua preocupação em manter a história desses povos que habitaram a aldeia indígena no passado, e agora os Dias-Marrecas descendentes dos indígenas habitam a mesma área, que passou de aldeia para fazenda e posteriormente se tornou o assentamento Saco:

eu conversei muito com o Dotô Wilia, que foi uma pessoa daqui, um advogado, e juiz de direito quando ele chegou a falecer, e ele conversou muito cumigo já na sua idade, recentemente a uns quatro ano atrás, aí ele conversou cumigo, a esse respeito, e me falano ... conversando cumigo e mim falano. Ele tem um livro da história aqui de Caracol, aí ele mim falou: "Zé Dias! Rapaz eu quiria conversar uma coisa cum você, eu quiria dizer pra você que resgatasse o nome Dias Marreca e não dexasse esse sobrenome disaparicer, você dexasse, colocasse todo mundo e colocasse im dias essa questão, por que quando na época o Machtim Valte [Martins Walter]" - que foi os primeiro prefeito que tiveram aqui, ele mim disse - "eu falei com Valte [Walter], que na época quando ele foi prefeito conversei cum ele que acharia qui divia fazer uma comunidade assim uma agrovila somente dessa família de gente que o povo chama caboco aqui, Dias Marreca, fizesse uma comunidade só cum esse povo, por que era uma história pra ficar essa história, por que no início aqui no Assentamento Saco, hoje onde o Assentamento Saco, era uma aldeia de índio, e nois somo pessoa descendente desses índio" (DIAS, 2016).

O propósito da criação da agrovila seria, então, resgatar o sobrenome Dias-Marreca e não deixar que o mesmo desaparecesse. Zé Dias justifica a importância da manutenção dos Dias-Marreca: "hoje onde o Assentamento Saco, era uma aldea de índio, e nois somo pessoa descendente desses índio". É importante considerar essa narrativa: "nois somo pessoa descendente desses índio", o autorreconhecimento como indígena por parte de Zé Dias não deixa dúvidas que os Dias-Marreca são de fato indígenas, mas não para por aí, Zé Dias traz outro elemento importante para endossar a narrativa dos Dias-Marreca como povo indígena:

[...] esses nome e resgatar essa família indígena que é uma coisa que traz muito atenção, eu tenho um tio que ele saiu daqui, Ele saiu daqui de Caracol, é irmão de minha mãe, por nome João José, que ele tá aproximadamente cum setenta ano, oitenta que saiu daqui, quando foi um ano desses uns dez anos atrás, aí um fii dele procurou através aqui da rádio, telefonou pra rádio que tinha aí ni Caracol, a rádio serra das confusões, e mandou procurar uma pessoa da família dele, fulano de tal, deu o nome e tudo e a professora que trabalhava lá esposa dum rapaz que trabalhava lá, mim chamou: "Zé, eu tô aqui cum a pessoa aqui qui ligou de lá de Buri ... Butirama aqui na Bahia, e ele quer saber uma pessoa da família, pra conversar com uma pessoa da família, aí ele deixou esse número de telefone". Aí eu liguei pra lá, quando liguei pra lá, aí Ele mim falou: "Zé Dias, rapaz é ... sou ... é seu primo, é seu tio qui mora aqui já a muitos ano e ele tá já muito velho e tá prestes a falecer, e ele tá dependeno dos remédio que é da FUNAI, e a FUNAI ... Ele mora 
numa bair ... numa comunidade indígena aqui, lá na Bahia, e tá recebeno os remédio pela FUNAI, e pricisava de uma história, de uma coisa qui trouxesse a respeito de descendência de índio pra ele puder consegui a receber essa medicação. Aí eu disse: não rapaz, tem problema não eu tô aqui, eu tenho aqui o livro da história que tá contano a história, tem até o nome do pai Dele, do tio dele qui tá no livro, eu vou mandar esse livro, livro pra você (DIAS, 2016).

$\mathrm{Na}$ narrativa acima mostra que além da autoafirmação como indígena, Zé Dias também ajudou um tio que se encontravam numa aldeia indígena na Bahia, onde o mesmo necessitava de uma "prova" para a FUNAI no sentido de reconhecê-lo como indígena, assim, poderia fazer uso de remédios distribuídos por esta instituição. Zé Dias enviou para seu tio um livro que conta a história dos Dias-Marreca, e consequentemente lá encontraria o nome dos familiares do tio de Zé Dias, ou seja, a "prova" requerida. Muito além de se identificar como indígena, a história dos Dias-Marreca foi usada para identificar um familiar numa aldeia fora do território piauiense. A auto declaração e consciência de sua identidade indígena nos permite inferir que a memória subterrânea, a memória dos indígenas que se tentou silenciar durante centenas de anos, ainda resiste, como nos ensina Michel Pollak, as memórias subterrâneas "prosseguem seu trabalho de subversão no silêncio e de maneira quase imperceptível afloram em momentos de crise e sobressaltos" (POLLAK, 1989, p. 05). Nesse sentido, apesar da relativa negação da identificação e do pertencimento a etnia Pimenteira a que já aludimos, percebe-se que alguns descendentes resinificam essa memória indígena de acordo com seus interesses mais imediatos no presente, no caso em tela, o interesse em ter acesso à tratamento de saúde realizado pela FUNAI.

O livro de William Palha Dias, Caracol na história do Piauí que Zé Dias faz referência conta um pouco sobre os Dias-Marreca. Palha Dias extraiu alguns depoimentos das histórias de sua família e narrativas contadas também pela família Dias-Marreca. O livro serviu para fortalecer o reconhecimento da família como indígena. Zé Dias comenta como William Palha Dias se impressionou em saber que como os Dias-Marreca tornaram a viver na mesma terra que seus antepassados indígenas viveram, Zé Dias se torna presidente de uma associação em terras que um dia foi aldeia e moradia de seus ancestrais. O retorno as terras da antiga aldeia é uma forma de manutenção da história dos Dias-Marreca, como o próprio Zé Dias fala: "é uma história que num é era pra acabar, e não é pá acabar":

Ele disse: "eu mim adimir ... o que é de impressionar, o que é de impressionar é qui eu fico pensano, como eu já fiz esse livro fiquei 
pensano", - que nesse livro tem até é ... nome de tio meu lá antigo que ele colocou na história, que foi dos primeiro que teve aqui nessa ... em Caracol e tudo, ele disse: "o que é de impressionar é que eu fiquei veno a situação, você vê você é descendente de índio, e lá no Saco era uma aldeia de índio que morava lá, aí você nasceu aqui no município de Caracol, e agora cumo prisidente duma associação, saiu aqui da cidade e foi lá pru local aonde era a aldeia de índio. Quer dizer, qui isso é que mim chamou atenção é da ... de ... fazer aquela vivencia desse ... resgatar, purquê a gente viu que você como descendente foi lá cum um grupo de pessoa e se arranchou lá no lugar onde era a aldea de índio, e binificiano esse povo", - qué dizer qui isto é ... é uma história que num era pra acabar, e não é pá acabar. (DIAS, 2016).

Zé Dias continua sua narrativa destacando novamente a importância da manutenção dos Dias-Marreca em sua comunidade de origem. O reconhecimento dessa identidade indígena pelos moradores da comunidade Saco muda de figura quando se trata das autoridades políticas. Zé Dias traz à tona a ausência de valorização da identidade dos DiasMarreca como povo indígena por parte dos representantes políticos de Caracol "eles acha que essas coisas não tem uma mínima importância, mais é a coisa que tem mais importância é uma história dessa". Assim como nosso primeiro entrevistado, Ronivon Sousa, Zé Dias destaca a vida simples dos Dias-Marreca, invocando uma narrativa recorrente: "eles acha que pobre não pode ter história" a narrativa de Zé Dais endossa a narrativa de outros entrevistados, que falam direta ou indiretamente da tentativa do silenciamento da memória indígena. Na própria comunidade Saco há grupos de pequenos comerciantes que tentam criar uma nova memória para a comunidade, como a mudança de nome da comunidade e propagação da inferioridade dos Dias-Marreca em relação aos outros moradores da comunidade. Em geral os descendentes dos indígenas são pessoas pobres que vivem na agricultura de subsistência e não tiveram a oportunidade de serem alfabetizados:

Aí nois viemo prá cá, e daqui ele disse que ... "Olhe, eu quero qui você prucure a ... resgatar esse sobrenome e a partir daí você também colocar no povo, se a ... trabalhe tudo unido e procurar a se conscientizar com, fazer um lugar pra que fique só essa família e fique na história”, mais infilismente não é possível por que nossos administradores eles num vê isso, eles não vê isso e os administrador ele ... ele vai olhar pra pessoa, quando a pessoa tem uma condição evoluída que ele pode se apuderar também daquilo, e não ver a nicidade da pessoa pobre pra ter uma história, que eles acha que pobre não pode ter história, mais é da onde eles tão cresceno é com a história dos pobres, é com o nome dos pobre que eles tão cresceno, mais num tão veno isso, então a rente tem procurado a fazer isso. (DIAS, 2016). 
Os códigos de linguagens e as memórias dos indígenas mais velhos se estabelecem principalmente pela narrativa oral, essas memórias confinadas ao silêncio foram transmitidas de uma geração a outra oralmente (POLLAK, 1989). A oralidade foi e ainda é uma estratégia pela disputa de identidade, mas, há outras estratégias, Zé Dias por exemplo é uma liderança política da comunidade.

\footnotetext{
Eu, eu sufri muito aqui no iniço, cumo prisidente da sociação inclusive agora eu tive trabalhano aqui cum ... eu trabalhei aqui uns ano com ... um grupo de pulítico que ... a rente não pode dexar fora essas coisa, e aí ... principalmente quando você não tem condição, qui muitas vezes tá dependeno dessas pessoa, trabalhei com um grupo de pulítico aqui e agora recentemente aquele grupo que eu trabalhava eu ... eu... não deu mais pra mim trabalhar com eles, não por que tivesse uma desavença cum eles e nada, absulutamente não, são pessoa muito educados, pessoas que me tratam muito bem, mais você sabe, você trabalha cum tipo de coisa que chega um momento que você tem qui mudar pra outra coisa pra vê se você consegue a resgar outra coisa, a fazer outra coisa que num vinha fazeno, aí foi o meu caso. (DIAS, 2016).
}

A inserção no campo político é uma forma de lutar por políticas públicas para a comunidade, a própria criação do Assentamento Saco se insere nessa celeuma de disputa por memória, Zé Dias foi por muito tempo presidente da associação do assentamento, hoje seu irmão Valdemar Dias ocupa a presidência da associação do assentamento Saco. Zé Dias esclarece em sua narrativa os motivos para sua participação com grupos políticos: "a rente [a gente] não pode deixar fora essas coisa, e aí... principalmente quando você não tem condição". A narrativa traz à tona novamente a questão da condição financeira precária dos moradores do assentamento onde está inserida a família Dias-Marreca.

Quando afirmamos que o campo político é um campo de disputa por memória queremos ressaltar que tal disputa ocorre também nas discussões frente a uma comunidade que tem mais de uma associação. Como mecanismo de disputa no campo político partidário foi criado outra associação dentro da comunidade. Essas disputas têm como aparência apenas disputas políticas partidárias, todavia, escondem outras intenções. A disputa é por memória, a reivindicação de memória é a causa principal das disputas políticas dentro do assentamento Saco, um dos objetivos da criação da segunda associação dentro do Assentamento foi a mudança do nome do assentamento Saco, para o nome de um antigo fazendeiro. Criar uma nova associação também foi a forma de combater as memórias dos indígenas, que até então são protagonistas da história do assentamento Saco: 
Aconteceu quando se teve a iniciativa, e o interessante disso que partiu ... principalmente a Associação dos Pequenos Produtores Rurais do Assentamento Saco, pela história partiu de um cidadão chamado José Dias, quer dizer partiu de iniciativas tanto do governo e tudo, mas a primeira associação foi criada com a presidência de uma cidadão chamado José Dias, conhecido como Zé Cabuquim. Entendeu? Que foi justamente o cara que liderou a associação de apropriação das terras né, que ia gerenciar né, essa parte administrativa né, da questão da rea ... reapropriação de terras, e enfim, de casas da própria comunidade. Sim, isso causou um descon ... um desarranjo considerável e o desconforto pra muita gente? Sim, causou, porquê o Zé Cabuquim é descendente direto, direto, dos Dias Marrecas. Entendeu? E ... é o seguinte é um caboco como eles dizem, tanto é o próprio nome, como eles dizem: Zé Cabuquim é um próprio caboco, de repente, como já venho dito antes né, pra não se alongar muito, a comunidade é feita, basicamente constituída por pessoas, com esse, fazer como o cara, com essa pendência de ... de requisitos que seria interessante se encaixar em outro, outra elite, por exemplo são pessoas de baixa renda, sem terra pra trabalhar. Entendeu? É ... negligenciado, jogado nas partes periféricas da cidade sem ter perspectiva de como viver de como produzir. Entendeu? Que viviam pelos cantos pela rua, que de repente tinham terra pra produzir, ou seja, o que se esperariam do ... duma perspectiva do ponto de vista, ou vendo um cenário de Brasil, esperaria de uma comunidade formada com pessoas, com cidadãos né, vamos dizer assim, é claro cidadãos, com esse perfil? Entenderia se que ela seria negligenciada, e que seria preconceituosa [discriminada], que ela seria justamente vítima né ... de apontamentos e de termos pejorativos, por conta justamente de que a base formativa desse povo já vem da própria ... da exclusão, já vem da própria exclusão (ROCHA, 2016).

A narrativa mostra as relações de disputa de memória que motivaram a criação da segunda associação do assentamento Saco, primeiro, seria um descontentamento por parte de alguns moradores do assentamento visto que a liderança da comunidade seria Zé Dias, um homem pobre e liderança da família Dias-Marreca, a segunda associação foi criada para deslegitimar a figura das pessoas que eles chamam de cabocos, lembrando que o termo “caboco" é usado comumente de forma pejorativa.

Ricoeur defende que "não é apenas com a hipótese da polaridade entre memória individual e memória coletiva que se deve entrar no campo da história, mas com a de uma tríplice atribuição de memória: a si, aos próximos, aos outros" (RICOEUR: 2007. P. 133-4). O que Ricoeur apontou como relacional entre o "eu", o "próximo" e "os outros" inspirou-nos a pensar principalmente nos "outros" como sendo aquilo que aparece nas interpretações construídas pelos produtores das narrativas orais, como sendo a expressão de valores, desejos, expectativas de um grupo, tentando se reafirmar em oposição a outro. 
A família Dias-Marreca é um dos fios da memória que merecem destaque para se perceber a tênue relação entre memórias concorrentes, no que diz respeito a relação entre indígenas e não indígenas. Zé Dias, nosso entrevistado mostrou-se um homem simples, como boa parte dos moradores do assentamento. A serenidade na sua narrativa em falar dos problemas que passa a comunidade por conta da seca vem com a mesma firmeza em falar sobre os indígenas da região, o sobrenome Dias-Marreca é motivo de orgulho para seus detentores, em maior ou menor grau.

\section{CONSIDERAÇÕES}

Quando elegemos a temática indígena como problemática para esta pesquisa, nos deparamos com a dialética da história, memória e identidade. A memória é, sem dúvida, uma das matérias primas para a construção da história e também na construção de identidades. É importante destacar que por longos anos se contava que os indígenas do Piaú foram exterminados, o ensino de história do Piauí, especialmente nos conteúdos de história indígena foram instrumentos da narrativa do silenciamento dos indígenas. Livros como, pesquisas para história do Piauí, do historiador Odilon Nunes, tornou-se o principal instrumento para ensino da história do Piauí. Que história é essa contada por Odilon Nunes? Em larga medida trata-se da história das elites agrárias, trata-se da seleção de documentos produzidos por homens ligados ao aparelho do estado colonial. Por longos anos ensina-se a história das elites coloniais, encontrou-se no ensino de história o instrumento de colonizar as mentes, instrumento para silenciar a memória indígena.

Os fios latentes da memória encobertos muitas vezes pelo estigma da herança colonizadora, hora e outra nos mostrava nos depoimentos orais, as disputas da memória entre o sangue indígena e os mitos fundadores de boa parte das comunidades que tivemos acesso. A memória é elemento essencial da narrativa histórica e a atua na construção de identidades que potencializam o pertencimento social, ou seja, potencializa as identidades.

A partir das narrativas orais e da observação in locu, apresenta-se uma comunidade com feições e principalmente com costumes indígenas, muito embora não haja um grupo indigenista, que lute pelo direito à identidade e direito à terra indígena. Preservam-se nas famílias memórias de autoafirmação.

No casso específico da comunidade Saco, na zona rural de Caracol/PI, o fio que conduz a memória e a identidade indígena se estabelece mais perceptível, primeiro pelo 
motivo da comunidade ser apresentada na memória social como "terra dos cabocos", a família Dias-Marreca, se constituí como o núcleo familiar mais importante para se discutir as negociações de identidade indígena, não só na região estudada, mas sim em todo estado do Piauí. Entender a constituição étnica dos Dias-Marreca é entender como os índios do Piauí negociaram a manutenção de uma memória indígena. Primeiramente os indígenas negociaram com os negros fugidos das fazendas, se uniram etnicamente e montaram estratégias para dificultar o avanço do colonizador sobre eles. Aos poucos os indígenas foram forçados, ou negociaram sua introdução ao convívio com elemento branco. As feições indígenas são interpeladas muitas das vezes como o sertanejo, ou caboclo. Talvez de imediato destaquemos elementos indígenas relacionados à alimentação como o cultivo da mandioca e a produção do beiju, ou o uso das plantas para cura, ou até mesmo a herança genética. Mas o que podemos destacar é a forma de transmissão da memória através da linguagem oral, a oralidade é um mecanismo inestimável nas relações sociais indígenas é por ela que o campo de confronto com a história oficial se estabeleceu.

O convívio com os entrevistados serviu principalmente para retirar qualquer dúvida sobre a presença indígena no Piauí, homens e mulheres, resistentes às intempéries da vida, muito embora a identidade não seja solida como a rocha, a identidade indígena se assemelha como a metáfora da argila retirada da terra, se molda com o tempo, mas se mantém resistente. No caso indígena foram perseguidos, mortos escravizados, por fim silenciados, conduto, permanecem vivos, resistentes, e agora muitos se afirmando como indígena como é o caso do Zé Dias da Família Dias-Marreca que se move numa uma estrutura de sentimentos mobilizando a linguagem que deixa vazar os interesses, tanto individuais quanto sociais, as tensões, as disputas, as estratégias políticas, sociais e culturais.

\section{Referências}

DIAS, Claudete Maria Miranda. História dos Índios do Piauí. Teresina, EDUFPI/GRAFICA DO POVO: 2011.

DIAS, José. Depoimento. [Caracol-PI, junho de 2016]. Entrevistador: Rafael da Silva Assis.

DIAS, William Palha. Caracol na história do Piauí. 4ª ed. Teresina, 2003.

KESTERING, Celito; SOUSA Gizelle Santos de. UMBUZEIRO DOS DEFUNTOS: Um marco na História de São Lourenço do Piauí. Cadernos do Lepaarq, Vol. XI, n²2, 2014. 
NORA, Pierre. Entre Memória e História: a problemática dos lugares. Projeto História, n.10, São Paulo: EDUSC, 1993.

NUNES, Odilon. Pesquisa para a história do Piauí: Pré-história. Primeiros contatos com a terra. Primórdios da colonização e ausência de governo. Primeiros. Teresina: FUNDAPI; Fund. Mons. Chaves, 2007.

POLLACK, Michael. Memória, esquecimento, silêncio. Revista Estudos Históricos, v. 2, n. 3 (1989), p. 3-15.

PORTELLI, Alessandro. Ensaios de História Oral. São Paulo: Letra e Voz, 2010.

RICOEUR, Paul. A memória, a história, o esquecimento. Campinas, SP: Editora da Unicamp. 2007.

ROCHA, Ronivon de Sousa. Depoimento. [Caracol-PI, junho de 2016]. Entrevistador: Rafael da Silva Assis.

WILLIAMS, Raymond. Marxismo e Literatura. Rio de Janeiro: Zahar, 1979. 